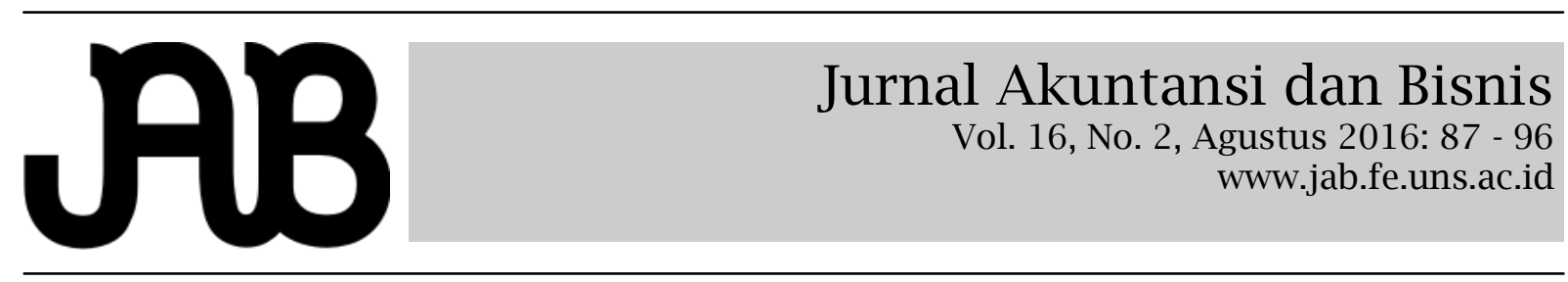

\title{
PENGARUH KONDISI KEUANGAN DAN POLITIK TERHADAP PERUBAHAN ANGGARAN PADA PEMERINTAH DAERAH DI INDONESIA
}

\section{AGUS PURWANTO}

\author{
Badan Pemeriksa Keuangan (BPK) Perwakilan Nusa Tenggara Timur
}

\begin{abstract}
A B S T R A C T
The purpose of this study is to obtain empirical evidence of the influence of financial autonomy, the accumulated surplus, revised surplus, political fragmentation and the years since the election of the budget changes districts/cities in Indonesia. The sample using the 59 districts/cities in Indonesia in 2012-2014. Sampling was done by using purposive sampling method. The analytical method used is multiple linear regression analysis models were performed with SPSS version 22.00. Results of regression testing showed that the accumulated surplus and financial autonomy have positive influence on changes to the budget, while the revised surplus have negative influence on budget changes. Political fragmentation and a year since the election have no effect on the budget changes.

Keywords : financial conditions, political, rebudgeting, $A P B D$
\end{abstract}

Tujuan dari penelitian ini adalah untuk memperoleh bukti empiris pengaruh otonomi keuangan, akumulasi surplus, revisi surplus, fragmentasi politik dan tahun sejak pemilu terhadap perubahan APBD kabupaten/kota di Indonesia. Sampel penelitian ini menggunakan 59 kabupaten/kota di Indonesia tahun 2012 sampai dengan 2014. Pengambilan sampel dilakukan dengan menggunakan metode purposive sampling. Metode analisis yang digunakan adalah model analisis regresi linier berganda yang dilakukan dengan bantuan program SPSS Versi 22.00. Hasil dari pengujian regresi yang dilakukan menunjukan bahwa akumulasi surplus dan otonomi keuangan berpengaruh positif terhadap perubahan anggaran, sedangkan revisi surplus berpengaruh negatif terhadap perubahan anggaran. Variabel fragmentasi politik dan tahun sejak pemilu tidak berpengaruh terhadap perubahan anggaran.

Kata kunci: kondisi keuangan, politik, perubahan anggaran, APBD

\section{PENDAHULUAN}

Anggaran merupakan pernyataan mengenai estimasi kinerja yang hendak dicapai selama periode waktu tertentu yang dinyatakan dalam ukuran finansial. Anggaran sektor publik penting karena beberapa alasan, yaitu karena anggaran merupakan alat bagi pemerintah untuk mengarahkan pembangunan sosial ekonomi, menjamin kesinambungan, dan meningkatkan kualitas hidup masyarakat. Anggaran juga diperlukan karena adanya masalah keterbatasan sumber daya sedangkan keinginan masyarakat yang tak terbatas dan terus berkembang, dan anggaran juga diperlukan untuk menyakinkan bahwa pemerintah telah bertanggung jawab terhadap rakyat. Dalam organisasi sektor publik pengang- garan merupakan tahapan yang cukup rumit dan mengandung nuansa politik yang tinggi (Mardiasmo 2009).

Menurut Undang-Undang Nomor 17 Tahun 2003 tentang Keuangan Negara, Anggaran Pendapatan dan Belanja Daerah (APBD) adalah rencana keuangan tahunan pemerintahan daerah yang disetujui oleh Dewan Perwakilan Rakyat Daerah (DPRD). Penetapan APBD dengan peraturan daerah sebelum tahun pelaksanaannya dimulai membutuhkan kompromi diantara budget actors yang memiliki preferensi berbeda (Abdullah dan Rona 2014).

Perubahan anggaran menjadi faktor umum dan signifikan dalam proses penganggaran di banyak kota (Forrester dan Mullins 1992). Menurut Peraturan Men- 
teri Keuangan (PMK) Nomor 15 Tahun 2016, Perubahan Anggaran terdiri atas; a) Perubahan rincian anggaran yang disebabkan penambahan atau pengurangan pagu anggaran, b) Perubahan dan/atau pergeseran anggaran dalam hal pagu anggaran tetap, dan/atau, c) Perubahan/ralat karena kesalahan administrasi. Anggaran yang telah disusun perlu direvisi kembali agar tepat tujuan dan sasaran sehingga tercipta anggaran yang efektif. Perubahan Anggaran tersebut tidak disajikan dalam Laporan Keuangan Pemerintah Daerah sebagai bentuk pertanggungjawaban pemerintah daerah kepada masyarakat. Hal tersebut menyebabkan banyak masyarakat yang tidak mengetahui perubahan anggaran yang terjadi dalam APBD, sehingga masyarakat tidak dapat mengendalikan dan mengawasi pelaksanaan APBD secara efektif.

Menurut Abdullah (2013), perubahan atas anggaran belanja terjadi karena prediksi atas sisa lebih perhitungan anggaran (SiLPA) tidak akurat, yang bersumber dari adanya perbedaan antara SiLPA 201a definitif setelah diaudit oleh BPK dengan SiLPA 201b, adanya pergeseran anggaran, perubahan dalam penerimaan, khususnya pendapatan. Perubahan dalam pembiayaan terjadi ketika asumsi yang ditetapkan pada saat penyusunan APBD harus direvisi.

Legislatif memiliki kewenangan untuk mengawasi pembangunan yang dilakukan oleh eksekutif. Akibatnya tekanan terhadap eksekutif menjadi semakin besar (Abdullah dan Asmara 2006), termasuk dalam proses penyusunan anggaran dan perubahan anggaran. Kewenangan legislatif untuk mengusulkan, merevisi atau menolak anggaran memunculkan konflik kepentingan diantara para penyusun anggaran. Perilaku ini terkait dengan peluang untuk mendapatkan keuntungan pribadi pada proyek-proyek yang akan dibiayai dengan APBD, yakni pengalokasian akan lebih banyak untuk proyek-proyek yang mudah dikorupsi (Mauro 1998a; 1998b) dan memberikan keuntungan politis bagi politisi (Keefer dan Khemani 2003).

Anesssi-Pessina et al. (2012) berpendapat bahwa penganggaran dan perubahan anggaran merupakan dua hal yang tidak dapat dipisahkan. Mereka menggunakan data dari sampel kota di Italia untuk menguji hipotesis tentang penyebab utama dari perubahan anggaran. Hasilnya perubahan anggaran sangat dipengaruhi oleh tingkat inkremental dalam proses penyusunan anggaran awal, serta oleh beberapa faktor penentu internal dan eksternal, seperti variabel politik, fitur organisasi, kondisi keuangan, dan lingkungan sosioekonomi setempat.

Sudah ada beberapa penelitian tentang perubahan anggaran tengah tahun, diantaranya Cornia et al. (2004) mengadakan penelitian mengenai perencanaan fiskal, budgeting dan rebudgeting dengan menggunakan pendapatan semaphore. Semaphore yang diusulkan adalah prosedur dimana ketidakpastian pendapatan secara langsung mempengaruhi perencanaan. Tujuannya bukan untuk membuat perkiraan yang lebih akurat, akan tetapi untuk membuat diskusi anggaran dan alternatif pendapatan yang lebih komprehensif.

Penelitian Forrester dan Mullins (1992) menemukan bahwa proses rebudgeting mempengaruhi kebijakan anggaran di tahun fiskal maupun dimasa yang akan datang. Penganggaran dan perubahan anggaran merupakan dua komponen yang memiliki karakteristik yang sama. Meskipun perubahan anggaran mungkin tidak signifikan mengorientasikan kebijakan publik, tetapi menawarkan nilai lindung terhadap ketidakpastian dan merasionalkan anggaran secara tidak menentu (Cornia et al. 2004).

Penelitian tentang perubahan anggaran di Indonesia juga sudah mulai banyak diantaranya Abdullah dan Rona (2014) meneliti pengaruh sisa anggaran, pendapatan sendiri dan dana perimbangan terhadap belanja modal dalam perubahan anggaran kabupaten/kota di Indonesia menemukan bahwa secara parsial hanya variabel dana perimbangan (diukur dengan perubahan DBH) yang berpengaruh terhadap perubahan anggaran belanja modal, sedangkan variabel sisa anggaran (diukur dengan perubahan SiLPA) dan pendapatan sendiri (diukur dengan perubahan PAD) tidak mempunyai pengaruh terhadap belanja modal. 
Abadiarti (2014) meneliti pengaruh tingkat inkremental penganggaran awal, kondisi keuangan pemerintah daerah dan sosioekonomi lokal terhadap rebudgeting pada pemerintah daerah di Indonesia menemukan bahwa variabel kondisi keuangan yang diwakili oleh akumulasi surplus, aliran surplus, revisi surplus tahun sebelumnya dan sosioekonomi yang diwakili oleh area geografis berpengaruh terhadap rebudgeting. Untuk variabel tingkat inkremental dalam proses penganggaran awal yang diwakilkan oleh perubahan belanja, perubahan belanja modal, dan perubahan belanja operasional, variabel kondisi keuangan yang diwakilkan oleh otonomi keuangan dan rigiditas pengeluaran, serta variabel sosioekonomi lokal yang diwakili oleh Pendapatan Domestik Regional Bruto (PDRB) tidak berpengaruh terhadap rebudgeting.

Purwaningtyastuti (2014) meneliti tentang rasio anggaran pendapatan dan belanja pemerintah daerah atas perubahan APBD. Ia menemukan bahwa selama tiga tahun pendapatan lain-lain yang sah mengalami perubahan anggaran yang paling besar. Perubahan belanja terbesar adalah perubahan anggaran belanja tak terduga. Adapun rasio realisasi pendapatan terhadap alokasi pendapatan pada APBD cenderung lebih besar dibanding realisasi terhadap perubahan APBD. Sedangkan rasio realisasi belanja terhadap perubahan APBD cenderung bernilai negatif, sedangkan rasio realisasi terhadap APBD bernilai positif atau melampaui alokasi belanja di awal tahun. Dengan demikian, perlu dilakukan perubahan anggaran agar tidak terjadi pelampauan anggaran.

Setiap pemerintah daerah di Indonesia melakukan perubahan anggaran setiap tahun. Perubahan anggaran tersebut tidak disajikan dalam laporan keuangan pemerintah daerah. Oleh karena itu, faktorfaktor yang mempengaruhi perubahan anggaran perlu diteliti agar dapat tercipta APBD yang efektif dan dapat memberikan manfaat yang sebesar-besarnya bagi rakyat. Disamping itu, penelitian-penelitian tentang perubahan anggaran sebelumnya tidak memberikan hasil yang konsisten. Proses penyusunan anggaran merupakan pros- es politik yang rumit sehingga penelitian ini bertujuan untuk menganalisa pengaruh kondisi keuangan dan politik terhadap perubahan APBD.

\section{T IN JAUAN PUS TAKA DAN PENGEMBANGAN HIPOTESIS \\ Perubahan Anggaran}

Perubahan anggaran merupakan salah satu aktivitas yang dilakukan aparat pemerintah daerah dalam aktivitas perubahan rincian anggaran belanja yang telah ditetapkan berdasarkan APBD dan telah disahkan dalam daftar isian pelaksanaan anggaran. Anessi-Pessina et al. (2012) menemukan bahwa persetujuan anggaran adalah hasil dari proses pengambilan keputusan, namun merupakan proses yang berkesinambungan dari proses pelaksanaan anggaran dan perubahan anggaran. Akibatnya, perubahan anggaran memiliki keterkaitan dengan beberapa variabel yang mempengaruhi proses anggaran.

\section{Kondisi Keuangan dan Perubahan Ang- garan}

Salah satu variabel yang mempengaruhi perubahan anggaran adalah kondisi keuangan pemerintah dan sumber daya yang lemah (Lu dan Facer 2004). Surplus yang terakumulasi di tahun-tahun sebelumnya lebih besar dalam penentuan penganggaran awal sehingga membutuhkan perubahan anggaran yang lebih besar pula. Hal yang sama juga berlaku, semakin tinggi otonomi keuangan yang berupa pendapatan asli daerah (PAD) maka semakin sedikit perubahan anggaran, semakin tinggi revisi tahun sebelumnya maka semakin rendah perubahan anggaran. Keganjilan yang ada adalah penganggaran dilakukan jauh sebelum laporan realisasi anggaran dibuat (Anessi-Pessina et al. 2012). Oleh karena itu, muncul surplus anggaran tahun lalu pada pertengahan tahun berjalan. Munculnya surplus ini akan merangsang adanya perubahan anggaran.

H1: Akumulasi surplus berpengaruh positif terhadap perubahan anggaran pada pemerintah daerah kota/kabupaten di Indonesia.

H2: Otonomi Keuangan berpengaruh negatif terhadap perubahan anggaran 
pada pemerintah daerah kota/ kabupaten di Indonesia.

H3: Revisi Tahun sebelumnya berpengaruh negatif terhadap perubahan anggaran pada pemerintah daerah kota/ kabupaten di Indonesia.

\section{Politik dan Perubahan Anggaran}

Perubahan anggaran dapat disamakan dengan reformasi dalam memodifikasi distribusi manfaat dan biaya antara berbagai pemangku kepentingan. Alesina dan Drazen (1991) menunjukkan bahwa fragmentasi politik menghalangi adopsi dari reformasi: fragmentasi politik bisa kemudian juga diharapkan untuk mencegah rebudgeting. Pada saat yang sama, bagaimanapun, koalisi mayoritas yang sangat terfragmentasi mungkin tidak dapat mencapai kesepakatan stabil dan berakhir menuntut perubahan anggaran yang berkelanjutan.

Shi dan Svensson (2006) berpendapat bahwa pilihan anggaran dipengaruhi oleh siklus pemilu. Dengan demikian secara alami akan berpengaruh terhadap rebudgeting, pilihan tersebut tidak langsung dimasukkan dalam anggaran awal. Lebih khusus, literatur menunjukkan bahwa pemilu mendatang mendorong peningkatan defisit dan mencegah reformasi fiskal, yang akan sebaliknya sering terjadi segera setelah pemilu. Oleh karena itu, sejak pemilu terakhir dapat diperkirakan mempengaruhi perubahan anggaran, dengan pemotongan belanja dan pajak atau biaya menjadi naik secara bertahap sebagai persiapan pemilu berikutnya. Selain itu, kecuali pemilu diadakan menjelang akhir tahun keuangan, administrasi harus beroperasi selama beberapa bulan dalam anggaran yang disetujui oleh para pendahulu mereka. Sehingga dapat diperkirakan akan ada perubahan besar dalam anggaran. Hal ini juga konsisten dengan Forrester dan Mullins (1992), yang menemukan perubahan anggaran yang didorong oleh perubahan prioritas dan kemauan untuk melawan keputusan sebelumnya. Ini adalah alasan lebih lanjut untuk mengharapkan bahwa perubahan anggaran terpengaruh waktu sejak pemilu terakhir.

Sama seperti penganggaran dipengaruhi oleh variabel politik, untuk menggabungkan prioritas dan kebutuhan yang muncul, hipotesis kami adalah bahwa perubahan anggaran akan dipengaruhi oleh variabel politik.

H4: Fragmentasi Politik (Jumlah partai politik di DPRD) mempengaruhi secara positif perubahan anggaran.

H5: Tahun Sejak Pemilu mempengaruhi secara negatif perubahan anggaran.

\section{METODE PENELITIAN}

Populasi dan Sampel

Populasi penelitian ini adalah seluruh wilayah kabupaten/kota di Indonesia. Sampel dalam penelitian dipilih dengan kriteria tertentu (purposive sampling) berdasarkan ketersediaan data yang disesuaikan dengan kebutuhan penelitian. Kriteria yang digunakan dalam pemilihan sampel penelitian ini yaitu, Kabupaten atau kota di Indonesia yang mempublikasikan APBD murni, ABPD setelah perubahan, dan laporan realisasi APBD tahun 2011 s.d. 2014 dan Kabupaten atau kota di Indonesia yang mempublikasikan daftar anggota DPRD periode 2010 s.d. 2014.

\section{Jenis dan Sumber Data}

Jenis data yang digunakan dalam penelitian ini adalah data sekunder yang berupa data APBD kabupaten/kota di Indonesia yang bersumber dari Direktorat Jenderal Perimbangan Keuangan (DJPK) Kementrian Keuangan, berupa data online yang ada di situs web www.djpk.kemenkeu.go.id. Data perubahan APBD dan laporan realisasi anggaran didapatkan dari Badan Pemeriksa Keuangan Republik Indonesia (BPK RI). Data jumlah partai politik dalam Dewan Perwakilan Rakyat Daerah (DPRD) diperoleh dari website www.jariungu.com. Data tanggal pelantikan kepala daerah di dapatkan dari web resminya Kementerian Dalam Negeri, yaitu www.kemendagri.go.id.

Penelitian ini merupakan penelitian pengujian hipotesis. Ruang lingkup penelitian ini dibatasi pada pengaruh akumulasi surplus, otonomi keuangan, revisi surplus, fragmentasi politik, dan tahun sejak pemilu terhadap perubahan APBD. Objek penelitian ini juga dibatasi pada APBD kabupaten/kota di Indonesia 
tahun 2012-2014.

\section{Definisi Operasional dan Pengukuran Var- iabel \\ Perubahan Anggaran Pendapatan Belanja Daerah (PAPBD)}

Variabel dependen dalam penelitian ini adalah perubahan belanja pada PAPBD karena belanja merupakan anggaran paling besar dan relatif lebih banyak berubah. Perubahan anggaran dihitung dari selisih anggaran belanja pada PAPBD dikurangi anggaran belanja pada APBD.

$$
\begin{aligned}
\text { PAPBD }= & \text { anggaran belanja pada PAPBD - } \\
& \text { anggaran belanja pada APBD }
\end{aligned}
$$

\section{Variabel Akumulasi Surplus (AkS)}

Akumulasi surplus dihitung dari akumulasi SiLPA dibagi dengan realisasi pendapatan. Dalam penelitian ini data yang digunakan adalah tahun 2012 - 2014, sehingga akumulasi surplus dihitung dari SiLPA tahun sebelumnya ditambah dengan SiLPA tahun berjalan, hasilnya dibagi dengan realisasi pendapatan tahun berjalan.

AkS $=$ SiLPA tahun berjalan + SiLPA tahun lalu / Realisasi pendapatan tahun berjalan

\section{Variabel Otonomi Keuangan}

Otonomi keuangan merupakan pendapatan asli daerah (PAD) tahun berjalan dibagi dengan realisasi pendapatan tahun berjalan.

\section{OtK = PAD tahun berjalan / realisasi pen-} dapatan tahun berjalan

\section{Revisi Surplus (RvS)}

Revisi surplus merupakan selisih anggaran surplus/defisit tahun berjalan dengan perubahan anggaran surplus/defisit tahun berjalan dibagi dengan perubahan anggaran belanja tahun berjalan.

$$
\begin{aligned}
\mathrm{RvS}= & \text { (anggaran surplus/defisit tahun ber- } \\
& \text { jalan - perubahan surplus/defisit } \\
& \text { tahun berjalan) / perubahan ang- } \\
& \text { garan belanja tahun berjalan) }
\end{aligned}
$$

\section{Fragmentasi Politik (FP)}

Fragmentasi politik adalah jumlah partai politik di dalam Dewan Perwakilan Rakyat Daerah (DPRD).

\section{Tahun Sejak Pemilu (TsP)}

Tahun sejak pemilu adalah selisih antara tahun anggaran (TA) APBD/PAPBD dengan tahun pelantikan kepala daerah.

$$
\begin{aligned}
\mathrm{TsP}= & \mathrm{TA} \text { APBD} / \mathrm{PAPBD}-\text { Tahun pelantikan } \\
& \text { kepala daerah) }
\end{aligned}
$$

\section{Metode Analisis Data}

Metode yang digunakan untuk pengujian hipotesis pada penelitian ini adalah metode analisis regresi linear berganda. Analisis regresi linear berganda digunakan untuk menguji hubungan antara satu variabel dependen dengan lebih dari satu variabel independen (Ghozali 2013). Selain itu, program aplikasi yang digunakan sebagai alat bantu dalam penelitian ini adalah SPSS 22. Persamaan regresi yang digunakan dalam penelitian ini yaitu:

$$
\begin{aligned}
A P B D= & \alpha+\beta 1 A k S-\beta 2 O t K-\beta 3 R v S+\beta 4 F P- \\
& \beta 5 T s P+\varepsilon
\end{aligned}
$$

Keterangan:

$\begin{array}{ll}\text { APBD } & : \text { Perubahan APBD } \\ \text { AkS } & : \text { Akumulasi Surplus } \\ \text { OtK } & : \text { Otonomi Keuangan } \\ \text { RvS } & : \text { Revisi Surplus } \\ \text { FP } & : \text { Fragmentasi Politik } \\ \text { TsP } & : \text { Tahun Sejak Pemilu } \\ \alpha & : \text { Konstanta } \\ \beta & : \text { Koefisien Regresi } \\ \varepsilon & : \text { Error }\end{array}$

\section{ANALISIS DAN PEMBAHASAN} Jenis dan Sumber Data

Desain penelitian ini menggunakan data sekunder yang telah dipublikasikan di website www.djpk.kemenkeu.go.id., portal.bpk.go.id, www.kemendagri.go.id dan $w w w$.jariungu.com. Penelitian ini merupakan pengujian hipotesis (hypothesis testing) dengan menguji hipotesis yang telah ditentukan sebelumnya.

\section{Sampel}

Sampel dalam penelitian ditentukan dengan menggunakan metode purposive sampling dengan kriteria sampel yang 
ditetapkan oleh peneliti sebagaimana dalam bab sebelumnya. Atas dasar kriteria pengambilan sampel yang telah ditetapkan, jumlah sampel penelitian dan observasi dalam penelitian ini dapat dipaparkan dalam Tabel 1.

Tabel 1.

Pemilihan Sampel

\begin{tabular}{lr}
\hline \multicolumn{1}{c}{ Kriteria sampel } & Jumlah \\
\hline $\begin{array}{l}\text { Jumlah kabupaten/kota 2012 } \\
\text { s.d. 2014 }\end{array}$ & 1542 \\
$\begin{array}{l}\text { Jumlah data PAPBD yang } \\
\text { diperoleh }\end{array}$ & 1397 \\
$\begin{array}{l}\text { Jumlah data PAPBD yang tidak } \\
\text { sesuai kriteria }\end{array}$ & 1220 \\
$\begin{array}{l}\text { Jumlah kabupaten/kota yang } \\
\text { menjadi sampel }\end{array}$ & 177 \\
\hline
\end{tabular}

\section{Statistik Deskriptif}

Berdasarkan hasil uji statistik yang disajikan pada Tabel 2, maka dapat diketahui bahwa jumlah sampel dari penelitian ini yaitu 177 kabupaten/kota di Indonesia dari total 3 tahun pengamatan. Tabel 2 juga menggambarkan mengenai variable PAPBD yang memiliki nilai minimum sebesar 21,33 pada Kabupaten Lebong, dan nilai maksimum sebesar 27,73 pada Kabupaten Berau. Nilai rata-rata sebesar 25,3630 dan standar deviasi 1,00527 .

Tabel 2.

Hasil Uji Statistik Deskriptif

\begin{tabular}{lrrrrr}
\hline \multicolumn{1}{c}{ Variabel } & N & Min & Max & Mean & Std. Dev \\
\hline PAPBD & 177 & 21.33 & 27.73 & 25.3630 & 1.00527 \\
OtK & 177 & -4.25 & -.95 & -2.4655 & .62883 \\
AkS & 177 & -3.28 & .40 & -1.5129 & .63493 \\
RvS & 177 & -4.61 & 1.41 & -1.0215 & .93373 \\
FP & 177 & 1.79 & 2.94 & 2.4221 & .23567 \\
TsP & 177 & .69 & 1.61 & 1.2140 & .32161 \\
\hline
\end{tabular}

Hasil pengujian variabel otonomi keuangan (OtK) menunjukan bahwa variabel tersebut memiliki nilai minimum sebesar -4,25 pada Kabupaten Bengkulu Tengah, dengan nilai maksimum sebesar 0,95 pada Kota Batam. Nilai rata-rata sebesar

$-2,4655$ dan standar deviasi 0,62883 .

Hasil pengujian variabel akumulasi surplus (AkM) menunjukan bahwa variabel tersebut memiliki nilai minimum sebesar 3,28 pada Kabupaten Aceh Utara, dengan nilai maksimum sebesar 0,4 pada Kabupaten Berau. Nilai rata-rata sebesar 1,5129 dan standar deviasi 0,63493.

Hasil pengujian variabel revisi surplus (RvS) menunjukan bahwa variabel tersebut memiliki nilai minimum sebesar 4,61 pada Kabupaten Sukabumi dan Kota Balikpapan, dengan nilai maksimum sebesar 1,41 pada Kabupaten Aceh Timur. Nilai rata-rata sebesar -1,0205 dan standar deviasi 0,93373 .

Hasil pengujian variabel fragmentasi politik (FP) menunjukan bahwa variabel tersebut memiliki nilai minimum sebesar 1,79 pada Kabupaten Kediri, dengan nilai maksimum sebesar 2,94 pada Kabupaten Sintang. Nilai rata-rata sebesar 2,4221 dan standar deviasi 0,23567.

Hasil pengujian variabel tahun sejak pemilu (TsP) menunjukan bahwa variabel tersebut memiliki nilai minimum sebesar 0,69 pada 34 Kabupaten, dengan nilai maksimum sebesar 1,61 pada 45 Kabupaten. Nilai rata-rata sebesar 1,2140 dan standar deviasi 0,32161.

\section{Uji Asumsi Klasik}

Penelitian ini telah memenuhi uji asumsi klasik, yaitu uji normalitas, uji autokorelasi, uji multikolonieritas, dan uji heterokedastisitas.

\section{Uji Signifikasi Parameter Individual Uji Statistik t \\ Persamaan regresi yang dapat dibuat ada- lah sebagai berikut:

$$
\begin{aligned}
\mathrm{PAPBD}= & 28,706+0,724 \mathrm{OtK}+0,518 \mathrm{AkS}- \\
& 0,182 \mathrm{RvS}-0,447 \mathrm{FP}+0,102 \mathrm{TSP}
\end{aligned}
$$

Berdasarkan persamaan tersebut dapat disimpulkan bahwa secara parsial variabel independen, yaitu otonomi keuangan (OtK) dan akumulasi surplus (AkS) mempunyai pengaruh positif terhadap perubahan anggaran, sedangkan revisi surplus mempunyai pengaruh negatif terhadap perubahan anggaran. Variabel fragmentasi politik dan 
tahun sejak pemilu (TsP) tidak berpengaruh terhadap perubahan anggaran. Hasil dari pengolahan data dengan bantuan software SPSS 2.2 dapat dilihat pada Tabel 3.

Tabel 3.

Hasil Uji Regresi Linier Berganda

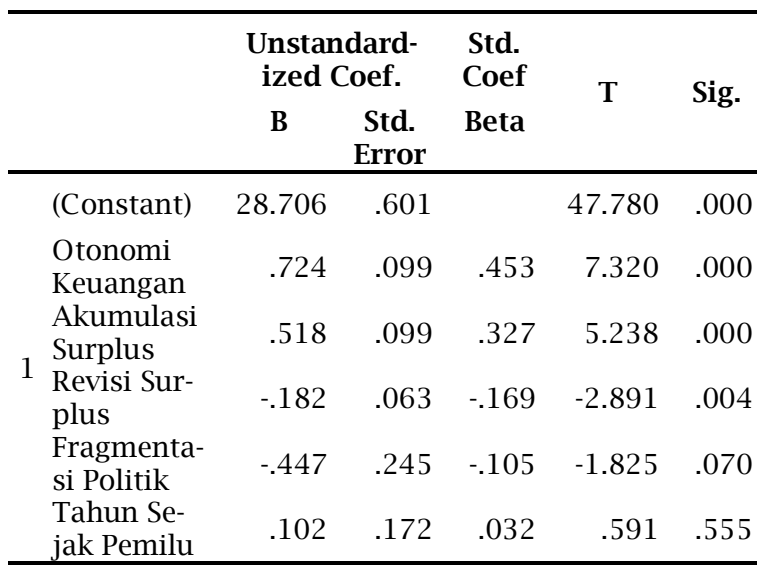

\section{Uji Koefisien Determinasi}

Berdasarkan nilai Adj. $\mathrm{R}^{2}$ koefisien determinasi model persamaan regresi memiliki nilai Adj. $\mathrm{R}^{2}$ sebesar 0,479 atau $47,9 \%$. Hal ini menunjukkan bahwa 47,9\% dari nilai variabel dependen yaitu perubahan anggaran dapat dijelaskan oleh variabel independen yaitu otonomi keuangan, akumulasi surplus, revisi surplus, fragmentasi politik dan tahun sejak pemilu. Sisanya sebesar 52,1\% tidak dapat dijelaskan oleh persamaan regresi atau dipengaruhi oleh faktor lain yang tidak termasuk dalam model analisis.

Tabel 4.

Hasil Uji Koefisien Determinasi

\begin{tabular}{lrrrr}
\hline Model & R & $\begin{array}{c}\text { R } \\
\text { Square }\end{array}$ & $\begin{array}{l}\text { Adjusted } \\
\text { R Square }\end{array}$ & $\begin{array}{l}\text { Std. Error of } \\
\text { the Estimate }\end{array}$ \\
\hline 1 & $.703^{\mathrm{a}}$ & .494 & .479 & .72574 \\
\hline
\end{tabular}

\section{Uji Signifikasi Simultan (Uji Statistik F)}

Pengujian ini dilakukan untuk menguji pengaruh variabel independen secara bersama-sama terhadap variabel dependen. Uji signifikansi dalam penelitian ini menggunakan tingkat signifikansi 5\%. Kriteria pengambilan kesimpulan adalah hipotesis penelitian diterima jika probability value ( $p$-value) $<0,05$.

Berdasarkan Tabel 5 dapat diketahui bahwa model persamaan ini mempunyai
Tabel 5.

Hasil Uji Statistik F

\begin{tabular}{lrrrrrr}
\hline \multicolumn{1}{c}{ Model } & $\begin{array}{c}\text { Sum of } \\
\text { Squares }\end{array}$ & Df & $\begin{array}{c}\text { Mean } \\
\text { Square }\end{array}$ & F & Sig. \\
\hline Regression & 87.793 & 5 & 17.559 & 33.337 & $.000^{\mathrm{b}}$ \\
1 & Residual & 90.066 & 171 & .527 & & \\
$\quad$ Total & 177.859 & 176 & & & \\
\hline
\end{tabular}

tingkat signifikansi a sebesar 0,000 , hal tersebut lebih kecil dibandingkan dengan taraf signifikansi $\alpha$ 5\%. Oleh karena itu, dapat disimpulkan bahwa variabel independen (OtK, AkS, RvS, FP dan TsP) dalam model ini secara simultan dapat berpengaruh terhadap variabel dependen.

\section{Akumulasi Surplus dan Perubahan Ang- garan}

Berdasarkan hasil yang diperoleh atas penelitian yang telah dilakukan, menunjukan bahwa akumulasi surplus berpengaruh positif terhadap perubahan anggaran belanja. Hal ini tidak konsisten dengan penelitian yang telah dilakukan oleh Abdullah dan Rona (2014) yang menyatakan bahwa akumulasi surplus tidak berpengaruh terhadap belanja modal. Namun, hasil penelitian yang didapatkan ini konsisten dengan penelitian yang dilakukan oleh Annessi-Pessina et al. (2012) dan Abadiarti (2014) yang menghasilkan bahwa akumulasi surplus mempunyai pengaruh positif terhadap perubahan anggaran belanja.

Akumulasi surplus dalam suatu tahun anggaran merupakan jumlah selisih lebih realisasi penerimaan dan pengeluaran anggaran (SiLPA) tahun lalu dan SiLPA tahun berjalan dibagi pendapatan total. Akumulasi surplus menjadi suatu pertimbangan dalam perubahan anggaran pendapatan dan belanja karena SiLPA tahun lalu ditetapkan setelah anggaran tahun berjalan ditetapkan, disamping itu SilPA tahun berjalan jumlahnya masih belum pasti. SiLPA ini dapat menjadi salah satu sumber penerimaan internal pemerintah daerah yang dapat digunakan sebagai sumber pendanaan untuk kegiatan maupun belanja tahun selanjutnya (Rizqiyati 2016). Tanda koefisien regresi untuk variabel akumulasi surplus sebesar 
5,238 , maka terdapat hubungan positif antara variabel akumulasi surplus terhadap variabel perubahan anggaran. Semakin tinggi akumulasi surplus dalam keuangan daerah, maka semakin tinggi perubahan anggaran.

\section{Otonomi Keuangan dan Perubahan Ang- garan}

Berdasarkan hasil yang diperoleh atas penelitian yang telah dilakukan, menunjukan bahwa otonomi keuangan dalam hal ini adalah realisasi pendapatan asli daerah (PAD) dibagi relisasi pendapatan total. Variabel otonomi keuangan berpengaruh positif terhadap perubahan anggaran belanja. Hal ini tidak konsisten dengan penelitian yang telah dilakukan oleh Abdullah dan Rona (2014) dan Abadiarti (2014) yang menunjukan bahwa otonomi keuangan tidak mempunyai pengaruh terhadap perubahan belanja. Hasil penelitian ini juga tidak konsisten dengan penelitian yang dilakukan oleh Annessi-Pessina et al. (2012) yang menghasilkan bahwa otonomi keuangan mempunyai pengaruh negatif terhadap perubahan belanja.

Tingkat ketergantungan yang masih tinggi terhadap pemerintah pusat melalui dana perimbangan mengakibatkan pendapatan asli daerah kurang signifikan dalam APBD. Otonomi daerah melalui pendapatan asli daerah belum sepenuhnya dapat memenuhi target yang ada. Semakin besar pedapatan asli daerah yang berasal dari pajak daerah, retribusi daerah, hasil pengelolaan kekayaan daerah yang dipisahkan, dan lain-lain pendapatan asli daerah yang sah, maka semakin besar pula pengaruhnya terhadap anggaran pendapatan dan belanja daerah. Berdasarkan hasil penelitian tersebut diharapkan pemerintah daerah dapat mengoptimalkan sumber pendapatan daerah yang dimiliki untuk meningkatkan pelayanan kepada publik.

\section{Revisi Surplus dan Perubahan Anggaran}

Hasil penelitian juga menunjukkan nilai signifikansi variabel revisi surplus tahun sebelumnya (RvS) sebesar 0,004 lebih kecil dari 0,05 , artinya bahwa variabel revisi surplus mempunyai pengaruh terhadap variabel perubahan anggaran. Tanda koefisien regresi untuk variabel revisi surplus tahun sebelumnya sebesar -2,891, maka terdapat hubungan negatif antara variabel revisi surplus terhadap variabel perubahan anggaran. Semakin tinggi revisi surplus dalam keuangan daerah, maka semakin rendah perubahan anggaran. Hal ini tidak konsisten dengan penelitian yang telah dilakukan oleh Abdullah dan Rona (2014) yang menunjukan bahwa revisi surplus tidak mempunyai pengaruh terhadap perubahan belanja. Namun, hasil penelitian ini konsisten dengan penelitian Annessi-Pessina et al. (2012) dan Abadiarti (2014).

\section{Fragmentasi Politik, Tahun Sejak Pemilu dan Perubahan Anggaran}

Hasil penelitian menunjukkan nilai signifikansi variabel fragmentasi politik (FP) sebesar 0,07 lebih besar dari 0,05, artinya bahwa variabel fragmentasi politik tidak berpengaruh terhadap variable perubahan anggaran. Disamping itu, hasil penelitian juga menunjukkan nilai signifikansi variabel tahun sejak pemilu (TsP) sebesar 0,555 lebih besar dari 0,05, artinya bahwa variabel TsP tidak berpengaruh terhadap variabel perubahan anggaran. Hal ini tidak konsisten dengan penelitian yang telah dilakukan oleh Annessi-Pessina et al. (2012) yang menunjukan bahwa variabel politik mempunyai pengaruh terhadap perubahan anggaran. Namun, hasil tersebut sesuai dengan penelitian yang dilakukan Forrester dan Mullins (1992) yang menunjukkan bahwa perubahan anggaran menjadi faktor umum dan signifikan dalam proses penganggaran dari banyak kota. Pemerintah daerah menggunakan perubahan anggaran untuk menyesuaikan program dan untuk memenuhi kebutuhan manajemen dalam lingkungan yang berubah.

\section{SIMPULAN}

Simpulan yang dapat diambil dari penelitian ini yaitu pertama, penelitian ini bertujuan untuk menguji pengaruh dari akumulasi surplus (AkS), otonomi keuangan (OtK), Revisi surplus (RvS), fragmentasi politik (FP) dan tahun sejak 
pemilu (TSP) terhadap perubahan anggaran. Kedua, Sampel yang digunakan dalam penelitian ini yaitu 59 kabupaten/kota yang ada di Indonesia tahun 2012-2014. Pengambilan sampel dilakukan dengan menggunakan purposive sampling. Ketiga, secara parsial variabel independen yang digunakan yaitu akumulasi surplus (AkS) dan otonomi keuangan (OtK) berpengaruh positif terhadap perubahan anggaran, sedangkan revisi surplus (RvS) berpengaruh negatif terhadap perubahan anggaran. Sedangkan variabel fragmentasi politik (FP) dan tahun sejak pemilu tidak berpengaruh terhadap perubahan anggaran. Keempat, secara bersama-sama otonomi keuangan (OtK), akumulasi surplus (AkS), revisi surplus (RvS), fragmentasi politik (FP) dan tahun sejak pemilu berpengaruh terhadap perubahan anggaran.

\section{KETERBATASAN DAN SARAN}

\section{Keterbatasan}

Keterbatasan dalam penelitian ini antara lain adalah Pertama, jumlah data yang dapat digunakan sebagai sampel terbatas. Hal ini disebabkan karena data DPRD periode 2009 sampai dengan 2014 tidak tersedia di website masing-masing daerah. Kedua, variabel independen yang digunakan masih menunjukan pengaruh yang relatif kecil, disamping itu variable fragmentasi politik (FP) dan tahun sejak pemilu tidak berpengaruh, sehingga diperlukan variabel independen lain yang lebih dapat menjelaskan variable dependen tersebut. Ketiga, penelitian ini tidak memisahkan sampel penelitian antara kabupaten dan kota dalam melakukan perubahan anggaran, sehingga tidak bisa membandingkan perubahan yang terjadi di kabupaten maupun di kota.

\section{Saran}

Saran yang dapat digunakan untuk penelitian selanjutnya adalah menambahkan periode pengamatan agar diperoleh jumlah sampel yang lebih banyak sehingga dapat terlihat variasi antar tahun pengamatan, menambah variabel lain yang memiliki pengaruh terhadap perubahan anggaran belanja dan penelitian selanjutnya dapat memisahkan antara kabupaten dan kota, sehingga dapat membandingkan bagaimana perubahan anggaran yang terjadi di kabupaten maupun di kota.

\section{DAFTAR PUSTAKA}

Abadiarti. 2014. Pengaruh Tingkat Inkremental Penganggaran Awal, Kondisi Keuangan Pemerintah Daerah Dan Sosioekonomi Lokal Terhadap Rebudgeting Pada Pemerintah Daerah Di Indonesia (Studi Informasi Website Pemerintah Daerah). Tesis, Universitas Sebelas Maret, Surakarta.

Abdullah, S. dan R. Rona. 2014. Pengaruh Sisa Anggaran Pendapatan Sendiri dan Dana Perimbangan terhadap Belanja Modal: Studi atas Perubahan Anggaran Kabupaten/Kota di Indonesia. Iqtishadia, 7(1): 179-202.

dan J. A. Asmara. 2006. Perilaku Oportunistik Legislatif Dalam Penganggaran Daerah. Simposium Nasional Akuntansi IX, Padang, Indonesia.

2013. Perubahan APBD. Diakses 28 November 2015, dari https:// syukriy.wordpress.com.

Alesina, A. dan A. Drazen. 1991. Why are Stabilizations Delayed?. American Economic Review, 81(5): 1170-1188.

Annesi-Pessina, E., M. Sicilia dan I. Steccolini. 2012. Budgeting and Rebudgeting in Local Government-Siamese Twins. Public Administration Review, 72(6): 875-884.

Cornia, G. C., R. D. Nelson dan A. Wilko. 2004. Fiscal Planning, Budgeting, and Rebudgeting Using Revenue Semaphores. Public Administration Review, 64(2), 164 - 179.

Eisenhardt, K. M. 1989. Agency Theory: An Assesment and Review. Academy of Management Review, 14(1): 57-74

Forrester, J. P. dan D. R. Mullins. 1992. Rebudgeting: The Serial Nature of Munidipal Budgetary Processes. Public Administration Review, 52(5): 467-474.

Ghozali, I. 2013. Aplikasi Analisis Multivariate Dengan Program IBM SPSS $21 \mathrm{Up}$ - 
JURNAL AKUNTANSI \& BISNIS| Vol. 16, No. 2, Agustus 2016: 87 - 96

date PLS Regresi. Edisi Ketujuh. Semarang: Badan Penerbit Universitas Diponegoro.

Jensen, M. C. dan W. H. Meckling. 1976. Theory of The Firm: Managerial Behavior, Agency Costs and Ownership Structure. Journal of Financial Economics, 3(4): 305-360.

Johnson, C. M. 1994. The Dynamics of Conflict between Bureaucrats and Legislators. New York: M.E. Sharpe.

Keefer, P. dan S. Khemani. 2003. The Political Economy of Public Expenditures (Background paper for WDR 2004: Making Service Work for Poor People). Amerika Serikat: World Bank.

Lu, H dan R. L. Facer. 2004. Budget Change in Georgia Counties: Examining Patterns and Practise. American Review of Public Administration, 34(1), 67-93.

Mardiasmo. 2009. Akuntansi Sektor Publik. Yogyakarta: Andi.

Mauro, P. 1998a. Corruption and The Composition of Government Expenditure. Journal of Public Economics, 69 (1998): 263-279.

1998b. Corruption: Causes, Consequences, and Agenda for Further Research. Finance \& Development (March): 11-14.

Republik Indonesia. 2005. Peraturan Pemerintah Republik Indonesia No 58
Tahun 2005 tentang Pengelolaan Keuangan Daerah.

Republik Indonesia. 2006. Peraturan Menteri Dalam Negeri No 13 Tahun 2006 tentang Pedoman Pengelolaan Keuangan Daerah.

Kementrian Keuangan. 2016. Peraturan Menteri Keuangan No 15 Tahun 2016 tentang Tata Cara Revisi Anggaran Tahun Anggaran 2016.

Purwaningtyastuti. 2014. Rasio Anggaran Pendapatan Dan Belanja Pemerintah Daerah Atas Perubahan APBD. Tesis, Universitas Sebelas Maret, Surakarta.

Republik Indonesia. 2003. Undang-Undang Nomor 17 Tahun 2003 tentang Keuangan Negara.

Rizqiyati, C. 2016. Pengaruh Pendapatan Asli Daerah (PAD), Sisa Lebih Perhitungan Anggaran (SiLPA), Luas Wilayah dan Pertumbuhan Ekonomi Terhadap Perubahan Anggaran Belanja Modal pada Pemerintah Kabupaten/ Kota di Indonesia. Surakarta. Skripsi, Universitas Sebelas Maret, Surakarta.

Shi, M. dan J. Svensson. 2006. Political Budget Cycles: Do Why?. Journal of Public Economics, 90(8): 1367-1389.

Sugiyono. 2014. Metode Penelitian Kuantitatif, Kualitatif dan R\&D. Bandung: Alfabeta.

Von Hagen, J. 2002. Fiscal Rules, Fiscal Institutions, and Fiscal Performance. The Economic and Social review, 33 (3): 263-284. 